\title{
Norman Horrocks Named Officer of the Order of Canada
}



The Faculty of Management at Dalhousie University is pleased to announce the appointment as an Officer of the Order of Canada of Dr Norman Horrocks, Professor Emeritus and Adjunct Professor, School of Information Management. This award recognizes "a lifetime of achievement and merit of a high degree."

"Norman is an inspiring leader in our profession," says Dr Fiona Black, Director of the School of Information Management. "He continues to work tirelessly to promote librarianship and information management, not only in Canada but around the world."

Dr Horrocks began his library career in Manchester, England, from 1943-53 interrupted by three years in the British Army's Intelligence Corps. He then worked in Cyprus, Western Australia and the U.S. before joining Dalhousie in 1971. He became Director of the School of Library and Information Studies (now the School of Information Management) and later was also Dean of the Faculty of Management. He left in 1986 to become Editorial Vice President of Scarecrow Press, a leading reference book publisher in Metuchen, NJ, until he returned to Dalhousie in 1995.

In 2004 Dr Horrocks was awarded the International Kaula Gold Medal, having earlier become the only person to have been elected to Honorary Membership in the three national library Associations-Canadian, British and American. Other awards received have been from the American Library Association, the Association for Library and Information Science Education, the Atlantic Provinces Library Association, Beta Phi Mu (the international honour society for library and information studies), Dalhousie University School of Information Management Associated Alumni, the New Jersey Library Association, the Nova 
Scotia Library Association and both Pittsburgh and Rutgers Universities. In 2003 the Nova Scotia Library Association established the Norman Horrocks Award for Library Leadership.

Norman has his BA in Constitutional History from the University of Western Australia, his MLS and PhD from the University of Pittsburgh, is a Fellow of the Chartered Institute of Library and Information Professionals of the UK and an Associate of the Library Association of Australia. He continues to be active in the School of Information Management and is an adviser and mentor to many, both in Canada and around the world. 